\title{
Roof Greening Study Based on the Urban Sustainable Development
}

\author{
Ruiqi Cao ${ }^{1, a}$ \\ ${ }^{1}$ Class1308, Yali High School, Changsha,Hunan,410000,China \\ a2247694730@qq.com
}

\begin{abstract}
Keywords: Roof Preening, Urban Environment, Building Space.
Abstract. In recent years, with the rapid development of the urban construction and the sharpening of the conflicts on urban land use, it has become the main topic that cities have potentials for sustainable development. People are getting more and more focused on environmental construction, and roof greening is becoming an effective way of urban greening. Roof greening enables to improve the physical performance of the building and save energy in a gardening way as one of the key combinations of gardening with the building.roof greening-roof greening.
\end{abstract}

\section{Introduction}

With the rapid development of the global economy, more and more obvious conflict between the sharp increase of the population and the ecological environment development. The pressure of the city from the sharp expansion of the population increases day by day in the limited urban space. The urban building density is higher and higher, the green area scale is smaller and smaller. The building energy consumption and the environmental pollution get more and more serious. The ecological system is damaged continuously. When people suffer from the revenge of the nature again and again, people finally realize the crisis awareness to the survival and development of themselves. The concept of "sustainable development" was proposed in China in 1980. The core content is "the harmonious development among the society, economy and the environmental protection". Therefore, it is necessary to strengthen the environmental protection and improve the ecological benefit of the building and the urban scope to construct the building and city with sustainable development.

\section{Overview of roof greening}

Generally, in the narrow sense, roof greening is the greening and gardening on the roof of a building. At present, there is no uniform national standard to define roof greening in China but different definitions appear on many local specifications. Roof greening is defined in Beijing's Roof Greening Specification (DB11/T281-2005) as follows: the greening on the top, roof and terrace of various buildings and structures that are above the ground and beyond the surrounding natural soil layer. roof greening.It is defined in the Technical Regulations of Roof Greening of Tianjin (2006) as follows: it is also called roof garden, referring to the greening on the roof of buildings. roof greening.It is defined in Technical Guideline of Roof Greening and Vertical Greening of Chengdu (Trial) (2005) as follows: the greening that the plants are planted on the building roof not connecting to the earth soil. The Shenzhen Government is sued the Measures for the Implementation of the Roof Beautifying and Greening in Shenzhen in 1999. The ways of uniform deployment of the city, fund raising in various ways and implementation state by stage were proposed to the roof beautifying and greening. It was required that the roof especially the roof of the high-rise buildings should be available with plants if the technology and the other objective conditions allow for greening or building the roof garden [1]-[5]. The experts from America and Germany were invited to the "First Term of Building Planting and Greening Seminar of China", which was held in Shenzhen in 2004, for academic report and exchange.

Beijing fulfilled its $100,000 \mathrm{~m} 2$ roof greening task in 2006, of which the simple roof greening covered an area of $73,000 \mathrm{~m} 2$ and gardening roof greening covered an area of $28,000 \mathrm{~m} 2$. Totally $100,000 \mathrm{~m} 2$ of roofs were greened in 2007. Beijing Government has included roof greening as a practical work for people. In recent years, in advantage of 2008 Olympic Games, roof greening has been booming in Beijing. In particular, the policies from the government provide the large 
development space for roof greening construction of Beijing.In brief, roof greening means the greening on various artificial overhead bases. The artificial base here mainly refers to the roofs of various buildings like hotel, residence, office building, plant and parking garage as well as the tops of other artificial structures like overhead flyover and overpass.

\section{Effect and function of roof greening}

Heat insulation.The greening on the top of the building can help improve the roof temperature significantly. It is approved by the experiment that in the hot summer, comparing with the roof without greening, the greening roof has the cooling effect. When the temperature is about $30^{\circ} \mathrm{C}$, the temperature of the roof without greening could be above $40^{\circ} \mathrm{C}$, while the temperature with greening roof is about $20^{\circ} \mathrm{C} 10 \mathrm{~cm}$ below of the base layer for the shielding of the green plants and the stromal effect with certain moisture. roof greening forms a natural air conditioner (Figure 1) to reduce the roof temperature. In winter, the greening roof is like a heat holding cover to protect the building roof. The plants and the base layer with the air layer could slow down the loss of the heat to have the heat insulation function.

Environmental Beautification. The greening on the top of the building not only takes no ground soil of the city, but also increases the greening area of the city. For the green plants could absorb the dust and the solid particle in the air, absorb carbon dioxide and emit oxygen, it has the function in certain degree to improve the urban air quality. On the other hand, the moisture in the plant leaf and roof greening stroma will be diffused in the air through transpiration and evaporation process to absorb the heat and decrease the temperature at the same time. Therefore roof greening (Figure 2) has also the function of humidifying and cooling as well as improving the micro-climate.According to the calculation of the related department of urban greening of Tokyo Japan, if roof greening of the city could reach $50 \%$, the city temperature could be reduced $0.84^{\circ} \mathrm{C}$ in the hot summer. This is very helpful to relieve the heat island effect of the city.

Water storage and moisture preservation. When the vegetation greening is taken on the roof, for the plants and the stroma could absorb and store the moisture, therefore, the roof drainage is reduced largely. According to the experimental data from the gardening station of Bavaria Germany, the drainage strength will be reduced by about $70 \%$ on the roof with the stroma thickness of $10 \mathrm{~cm}$. While delaying the roof drainage strength, the greening roof could store most part of rain through the stroma and plants, which will be evaporated through the transpiration of the plants and the evaporation of the stroma. Therefore, roof greening (Figure 3) not only reduces the burden of the sewer and the reservoir but also reduces the burden of the municipal drainage project.

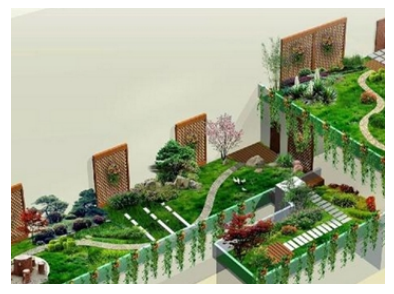

Figure 1 Lotus pond on the roof

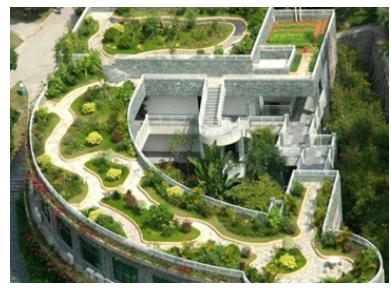

Figure 2 Roof greening for optimizing the environment

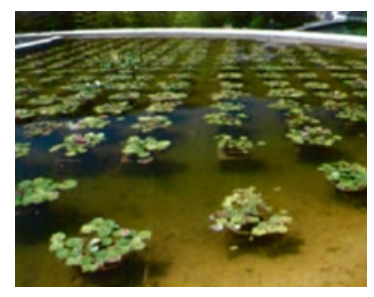

Figure 3 Roof greening for water storage and moisture preservation

Roof protection.Among the damages to the roof structure, few of them are caused by the over load of the roof. In most cases, it is the temperature change causes the break of the roof waterproof layer. The rapid change of the temperature difference has the special damage to the building structure. It could cause the swelling and shrinking of the roof structure to cause the fracture of the building, the water seepage and collapse. The temperature change could result in the aging of the roof materials and reduction of the service life. roof greening (Figure 4) could be for heat insulation and heat control in summer and for thermal insulation and preservation in winter to deduce the damage to the roof for the temperature difference, block the direct radiation of the sunshine to the roof as well, not only protecting the roof structure but also extending the service life of the roof. 
Function of sound insulation.With the concentrated population, heavy traffic flow and diversified social events in the city, noises have become one of the main sources of pollution. As plants can absorb the optical wave and acoustic wave, the roof greening (Figure 5) acts as a natural noise barrier.

Landscape effect.The beauty of the nature is the instinctive longing of the people. The green environment has the strong attraction to the mentality of the people. roof greening (Figure 6) could make the people feel the green landscape in new form, feel the breath of the nature, and experience the vigorous growth of the green plants in the inorganic world of concrete. People will experience the natural sense of beauty in the high altitude to produce the kind, relaxed and joyful metal feelings.

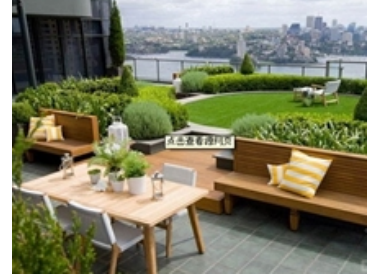

Figure 4 Greening for protecting the roof

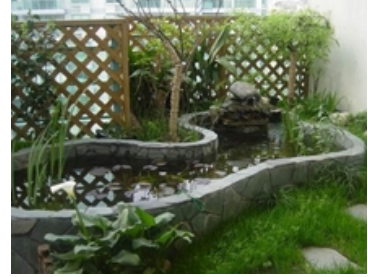

Figure 5 Sound insulation by greening

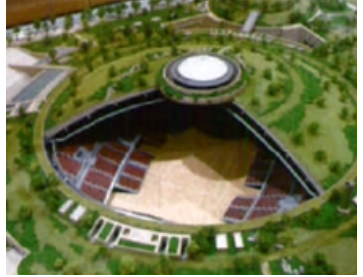

Figure 6 Landscaping by roof greening

\section{Classification of roof greening and relevant construction conditions}

There are a variety of classification methods as listed below: roof lawn, roof vegetable garden, roof orchard, roof pool, roof of wetlands, roof garden and roof exhibition garden (when divided by content); high-rise type and low-rise type when divided by height); flat roof greening, slope roof greening and curved greening roof greening (when divided by the architectural form of the roof). The design process [6] of roof greening demands for a complete understanding of both the spatial form of the construction roof (for the sake of good greening design ideas) and and the composition and structure (namely the construction foundation of roof greening) of the roof construction; with the premise that basic roof functions are guaranteed, new technologies and materials shall be applied positively so as to create various roof special form and to improve indoor environment.

Slope.All roofs shall have slope of certain degree. Different slope may have different requirements on roof material and greening material; therefore, slope has certain affect on roof greening. Generally speaking, the minimum degree of plane roof is $2 \%$ as per requirements in Code for Acceptance of Construction Quality of Roof (GB50207 - 2012); the drainage slope shall be $2 \%-3 \%$, and the structure sloping shall be $3 \%$, while material slope (also known as construction slope) is $2 \%$; for roof within this slope, rainfall can be drained, causing less load for the roof waterproof layer; on the other hand, anti-slippery measures are not necessary for washout ; this is an appropriate slope for greening.

Bearing capacity.For greening on the roof, first of all, we shall understand whether or not the construction roof can bear the load caused by various greening projects on the roof; all roof greening shall be carried out within the bearing capacity of the construction roof; the static load on the greening roof mainly includes loads caused by various structure layers as well as roof load caused by soft and hard elements for garden landscaping, such as garden architecture, sketch, garden road pavement, cultivate base material and water; live load of the greening roof mainly includes load of vegetation and flowers, human being, wind, rain, snow and floor stockpiling; There are certain requirements for load of various constructions in our current national industry building standards; for general roofs, live load shall be $2.0-2.5 \mathrm{KN} / \mathrm{m} 2(200-250 \mathrm{~kg} / \mathrm{m} 2)$; as a site for large-scale activity, the live load shall be $2.5-3.0 \mathrm{KN} / \mathrm{m} 2(250-3.0 \mathrm{~kg} / \mathrm{m} 2)$ as per requirements for balcony; the specified load capacity of construction in construction regulations of U.S.A is relatively high; the load for multi-balcony is $4.8 \mathrm{KN} / \mathrm{m} 2(480 \mathrm{~kg} / \mathrm{m} 2)$; for construction regulations in Japan, the allowable value for load of residential floor (including balcony) is $1.8 \mathrm{KN} / \mathrm{m} 2(180 \mathrm{~kg} / \mathrm{m} 2)$.

Waterproof capability.The construction of the waterproof layer is the key technology for roofing; currently there are two methods for waterproofing of roof greening, namely hard and soft water-proofing; generally speaking, hard waterproof layer is located on the top; detailed method is shown below: pave concrete with thickness of $50 \mathrm{~mm}$ on the roof; two-way reinforcement fabric piece 
shall be embedded inside with casting by concrete with addition of waterproof agent, water reducing agent and micro-expanding agent; the rigid waterproof layer is hard and can improve the performance against crack and penetration, offering protection for the roof; it is suitable for waterproof later for greening roof with advantages such as integrity, crack-proofness, anti-penetration and long life; it can also effectively prevent penetration by roots; it is most suitable to be used as waterproof later for roof greening[8]; for soft waterproof later, "three layers of asphalt felt and four layers of liquid asphalt" or "two layers of asphalt felt and three layers of liquid asphalt" shall be applied with combination of PVC cement or Polyvinyl chloride paint for processing; in addition, during waterproofing, waterproofing measures shall be taken for all pipelines, chimneys, drain holes, embedded iron parts and posts as well as all facilities higher than the roof; the overall waterproofing project may fail because of inappropriate processing of tiny part during waterproofing; drainage system shall be well arranged for roof greening; the layout of drainage for roof greening shall be in accordance with the slope of original rood; original drainage holes and slope shall not be blocked, isolated or altered; there shall be drainage pipeline under plantation pond of large plants, which shall be connected with roof drainage outlet for convenient discharge of excessive water; drainage pipeline is available under plant nutrition soil; filtering layer is placed on above and is consisted of nonperishable materials; a layer of ceramsite, gravel or other material with thickness of $8 \mathrm{~cm}$ shall be laid under; drainage hole shall be arranged along the flower pond with an interval of $8 \mathrm{~cm}$; retaining wall will be built around the roof top with drainage hole and gutter, convenient for flow and collection of excessive water (Figure 7).
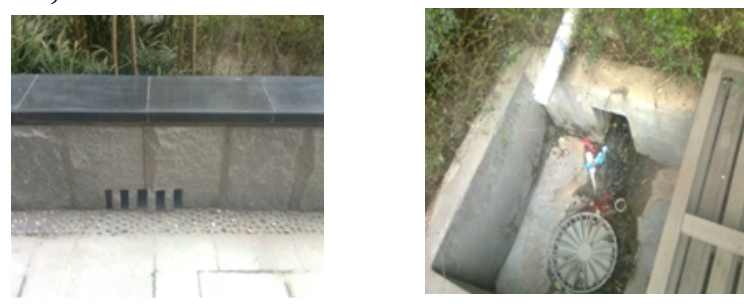

Figure 7 Drainage treatment for roof greening

\section{Investigation and analysis of roof greening in Changsha}

As the provincial capital of Hunan Province and the second largest city in central China, Changsha strives to turn itself into the most opened and most influential cultural famous city and world's tourism city,; climate in Changsha is sub-tropical humid monsoon climate with certain characteristics: obvious climate change, ample rainfall, rain and heat in the same period; four seasons are not obvious with only winter and summer; the annual average temperature is $17.2^{\circ} \mathrm{C}$; January is the coldest month with an average temperature between $4.4^{\circ} \mathrm{C}$ and $5.1^{\circ} \mathrm{C}$; winter crop can survive the winter with slow growth.

Roof greening in Changsha develops slowly, which is not widely acknowledged; with unsound governmental policies, simplex plant application without seasonal characteristics, lack of overall planning and ineffective reconstruction and greening for old buildings, difficulties in follow-up maintenance and poor maintenance effects (Figure 8); most citizens just plant vegetables on the roof with random construction; it is very messy, not to mention municipal landscape; all these show that Changsha pays insufficient attention to the reform of roof greening on old buildings.
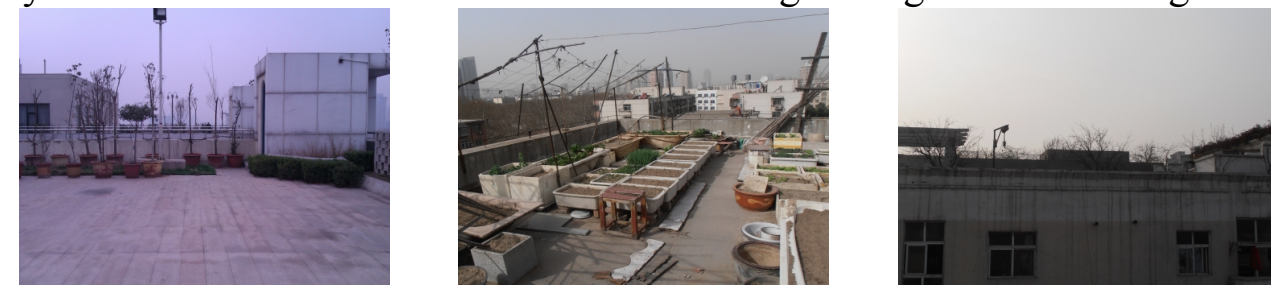

Figure 8 Roof greening of simple residential house

The roof greening area of residential house is relatively small, which is usually built by themselves with characteristics of easiness, simplicity and randomness; limited by the bearing structure, this kind of roof greening is usually the shape of belt; citizens design and arrange flower pond around the fence 
and on the bearing beam according to construction structure; plants used for roof greening is simple in variety; portable flower pond or pot is available.

For commercial constructions, the structure is solid and stable with relatively higher load and large area, which is used by lots people; therefore, it is usually like a tourism park; to attract people and increase activity site, merchants in Changsha usually expand the greening on the roof (Figure 9); abundant plants are used with arrangement of sketch, chairs and landscape lamp so as to create a healthy environment and to offer a green space for their leisure.
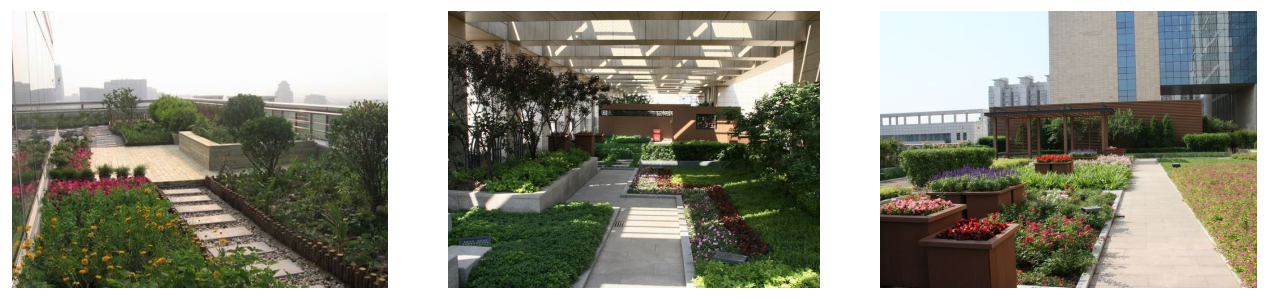

Figure 9 Touring roof greening

\section{Summary}

Roof greening can effectively relieve the urban heat island effect, reduce impacts by rainstorm, reduce soil and water loss, purify the urban air and reduce the urban noise pollution; it brings about significant ecological benefits and plays a key role in the sustainable development and energy efficiency of a building.

Roof greening in Changsha develops slowly with many problems; all these problems curbed the development of roof greening in Changsha; the application of plants on the roof is not abundant and lack of seasonal landscape; roof greening in Changsha accounts for only a small part of the urban construction area and is unsound; most of the roof area in Changsha is still idle. Therefore, roof greening in Changsha is still to be improved.

\section{References}

[1] DB 11/366-2006, Beijing Local Standard, Construction Technical Specification of Green Roofs Waterproof (2006)

[2] DB29/T 118-2004, Tianjin Local Standard, Technical Specification for Roof Greening in Tianjin(2004)

[3] DB11/T212-2003, Beijing Local Standard, Code for Construction and Acceptance of Landscape Engineering in City and Town(2003)

[4] DB11/T 281-2005,,Beijing Local Standard, Specification for Roof Greening(2005)

[5] DB440300/T 37-2009, Shenzhen Local Standard, Code for the Design of Roof Greening(2009)

[6] Han Lili, Li Lianlong and Ma Liya: Roof Greening on Sample Building of Ministry of Science and Technology concerning Energy Conservation[J].Archi Creation Magazine, 2004,(8): 138-139;

[7] GB 50009-2011, Load Code for the Design of Building Structure(2011)

[8] Hu Jun: Waterproofing Design of Green Roof . Chinese Waterproof Building, 2006 (1):63-67 
